\section{The sky isn't falling!}

Peter Ward

Cretaceous-Tertiary Mass Extinctions: Biotic and Environmental Changes. Edited by Norman MacLeod and Gerta Keller. Norton: 1996. Pp. 575. \$55, £40.

Dinosaur Extinction and the End of an Era: What the Fossils Say. By J. David Archibald. Columbia University Press: 1996. Pp. 237. \$57, £40 (hbk); \$29, £20 (pbk).

The Great Dinosaur Extinction Controversy. By Charles Officer and Jake Page. Addison-Wesley: 1996. Pp. 209. \$25.

RESEARCH in many disciplines of the geological sciences was transformed following the appearance in 1980 of a now celebrated paper by Luis Alvarez and colleagues. Dealing with the mass extinction that ended the 'age of dinosaurs', the paper generated a minor extinction pulse of its own - in trees killed for printing all the subsequent discussion of the topic. Now, as we approach the paper's twentieth anniversary, three new books join the mountain of published work that has already stemmed from it.

What many people are not aware of is that the Alvarez paper offered not one hypothesis, but two. First, the authors suggested that the Earth was hit by a large comet or asteroid some 65 million years ago. Second, they argued that the result was a mass extinction that wiped out many Mesozoic species including, most famously, the dinosaurs on land, and ammonites in the sea.

That Earth was hit 65 million years ago by a large body about $10 \mathrm{~km}$ across was confirmed to most scientists' satisfaction within five years of Alvarez's original publication. The physical scars of such an impact from numerous CretaceousTertiary boundary sites around the globe, together with the later discovery of a candidate crater (Chicxulub crater in the Yucatan peninsula in Mexico), have provided a preponderance of evidence that the Alvarez team was indeed correct in its first premise. That this impact was the main cause of a mass extinction, however, has been far more difficult to prove - or disprove. The best we have is a temporal coincidence of the impact with an extinction. This may be as good as the evidence will ever get; it has certainly been sufficient to convince many Earth scientists working on the problem.

Yet sceptics remain and, if the enormous amount of palaeontological research so far has not convinced them, perhaps nothing ever will. We are now seemingly in a phase analogous to a stubborn military retreat, with the pro-impact extinction group moving inexorably forward, and the anti-impact forces slowly giving up territory ("there may have been impact-generated extinction in the tropics, but not at higher latitudes"). But they are fighting a grim rearguard action as they retreat, taxonomic group by taxonomic group, biotic province by biotic province.

That some palaeontologists still remain sceptical is clear from these three very different books about the controversy. The multiauthored tome edited by Norman MacLeod and Gerta Keller is aimed at specialists, and results from a conference held in Boston several years ago. Its 20 chapters bring together a large mass of work, yielding much new interesting information. It spans the taxonomic and geographic gamut of Cretaceous-Tertiary locations, organisms and sedimentary patterns characteristic of the end of the Cretaceous period. Most chapters deal either with the stratigraphic distribution of Cretaceous organisms or with sedimentology or sea-level changes. Many of the authors of the chapters on sea-level change have difficulty divorcing observation from interpretation. Half of the chapters have as coauthor at least one leading critic of the impact hypothesis, such as Keller, MacLeod or Stinnesbeck. There are some useful chapters dealing with hypothesis testing, especially those by MacLeod and David Archibald, which I found first rate.

Archibald has expanded his chapter to produce a truly excellent book, Dinosaur Extinction and the End of an Era. Archibald and I are at opposite ends of the extinction controversy, but I highly recommend his book, especially to a general readership. It is lucid, well written, and presents the data on vertebrate, and especially dinosaur, extinction in a forthright and lucid way.

For the most part, these two books accept as fact that the Earth was indeed hit 65 million years ago. But The Great Dinosaur Extinction Controversy, by Charles Officer and Jake Page, discards as heresy even this largely accepted tenet. To begin with, one might be forgiven for thinking that this book was written as a parody, especially when one comes across sentences in the preface such as: "Indeed, most of the 'science' performed by the Alvarez camp has been so inexplicably weak and the responses to it so eagerly accepted by important segments of the scientific press (never mind the popular press and the tabloids) that some skeptics have wondered if the entire affair was not, on the impact side, some kind of scam." Unfortunately, one soon realizes that this is a grim rearguard action - something akin to the Roman Catholic Church's view of Bruno and Galileo in the seventeenth century.

There are some wonderful new views of the exciting years immediately following Alvarez's publication, as seen by the 'loyal opposition'. Yet there is much distortion in this book, such as the use of my data and publications (while never mentioning my own interpretation of the data) supposedly to "prove" that the ammonites became extinct gradually, not suddenly just the opposite of my findings.

Judging from these three books, it is clear that the dinosaurs, although long dead, are keeping the nature of their vanishing still controversial.

Peter Ward is in the Department of Geological Sciences, University of Washington, Seattle, Washington 98195, USA.

\section{New in paperback \\ Designing the Molecular World: Chemistry at the Frontier by Philip Ball. Princeton University Press, $\$ 16.95$, $£ 12.95$. "The whole book is pervaded by a sense of authority and comprehension", Peter Atkins, Nature 358, 550 (1994).}

At Home in the Universe: The Search for the Laws of Complexity by Stuart Kauffman. Penguin, £8.99. "This is a courageous book... I guarantee that any reader whose imagination has survived an academic education - or has never been exposed to one - will learn a lot, and be changed forever", Ian Stewart, Nature 379, 33 (1996).

The Faber Book of Science edited by John Carey. Faber, £9.99. "Everything an anthology should be: it is entertaining, stimulating and occasionally startling. Carey's reading is prodigious, and even the more familiar of his choices are illuminated by commentaries that crackle with literary and indeed scientific insights", Walter Gratzer, Nature 378, 111 (1995).

Touched with Fire: Manic Depressive Illness and the Artistic Temperament by Kay Redfield Jamison. Simon and

Schuster, £9.99. "An important work that should provoke some serious rethinking in several corners of academe", Hugh Freeman, Nature 362, 666 (1993).

Naturalist by Edward $O$. Wilson. Penguin, $£ 8.99$. "Provides detailed insights into the creation of a renowned scientist, and is an elegant account of the development of his exciting ideas", J. L. CloudsleyThomson, Nature 372, 291 (1994).

Lewis Carroll: A Biography by Morton N. Cohen. Papermac, $£ 12$. "The author's skill and tact in covering all aspects of Dodgson's complex, enigmatic personality is impressive", Martin Gardner, Nature 379, 127 (1996).

Darwin's Dangerous Idea: Evolution and the Meanings of Life by Daniel C.

Dennett. Penguin, $£ 9.99$. "Never in the field of scientific endeavour can so great a theory have been so widely misunderstood by so many with so little reason: but Dennet's book is a marvellous corrective", Mark Ridley, Nature 375, 457 (1995). 